Copyright (C) 2021 by Cherkas Global University

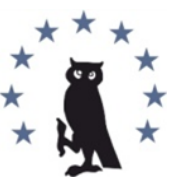

Published in the USA

Russkii Arkhiv

Has been issued since 1863 .

E-ISSN: 2413-726X

2021. $9(2): 210-223$

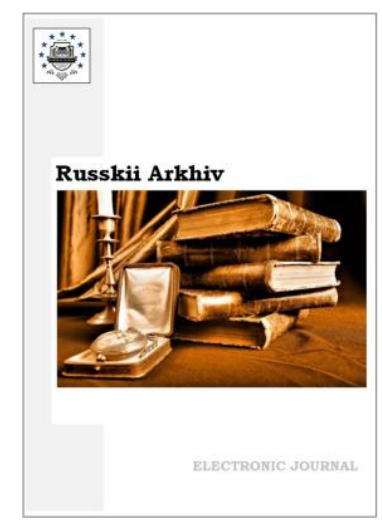

DOI: $10.13187 /$ ra.2021.2.210

https://ra.cherkasgu.press

\title{
"I Remember the Skewed Grain Elevator in the Calmed Down Town of Spitak": Memories of the Disaster Fighter of the 1988 Spitak Tragedy - Bulldozer Driver V.D. Savenkov
}

Preparation for publication, introductory article and comments

Vladimir D. Savenkov a, *

a Anton Chekhov Taganrog Institute (branch) of Rostov State University of Economics (RSEU), Russian Federation

\section{Abstract}

In December 1988, the leadership of the Rostov region was one of the first, along with the union republics bordering with Armenia, to provide humanitarian assistance, providing qualified specialists from the The Office of Mechanization $\mathrm{Nr} 2$ of the Trade and Construction Association "Rostovstroy" and specialized equipment necessary for restoration work.

The interview of Vladimir Dmitrievich Savenkov is dedicated to his activities as a disaster fighter of the consequences of the catastrophic Spitak earthquake. The respondent tells in detail how his conscription and transportation of equipment was carried out, how he had to adapt to the specifics of the military rescue operation and endure all the hardships associated with the peculiarities of emergency deployment to the place of emergency. Memories of V.D. Savenkov are valuable evidence of how the emergency situation in the Armenian SSR revealed the unpreparedness of the top party leadership headed by M.S. Gorbachev, in relation to the prompt elimination and prevention of major Urban Emergencies.

Keywords: V.D. Savenkov, Spitak earthquake of 1988, "Rostovstroy", disaster fighter, Armenian SSR, Rostov region, memories, oral history.

Спитакская трагедия стала следствием серии катастрофических по масштабу землетрясений, затронувших северо-запад Армянской ССР 7 декабря 1988 г. в 10 часов 41 минуту (по московскому времени). Колебание земной поверхности достигало 10 баллов из 12 допустимых по шкале Рихтера. Двукратная взрывная волна, пронесшаяся по планете, была зафиксирована не только отечественными научными лабораториями, ее также зарегистрировала аппаратура в научных лабораториях США и Австралии.

Землетрясение особенно сильно ощущалось в Армянской ССР, в соседних с ней Грузинской ССР и Азербайджанской ССР. В результате разрушительной катастрофы было выведено из строя 40\% промышленного потенциала Армянской ССР. Полностью был разрушен г. Спитак, остались погребены под земляными завалами 58 сел. В общей сложности пострадали более 300 населенных пунктов, погибли, только по официальным данным, около 25 тыс. человек (Катастрофы конца XX века, 1998).

\footnotetext{
${ }^{*}$ Corresponding author

E-mail addresses: savenkov.stalker2010@yandex.ru (V.D. Savenkov)
} 
Еще с 1970-х гг. руководство СССР столкнулось с чередой возросших лесных пожаров и локальных катастроф, разрушительные последствия которых удавалось с переменным успехом оперативно решать за счет экстренного привлечения армейских структур. Данные вызовы времени выявили на практике необходимость реформирования системы гражданской обороны. Однако, вплоть до декабрьской трагедии в Армянской ССР, унесшей огромное число жизней, волевых решений в данной сфере не было принято, несмотря на имевшие место прецеденты - самой крупной аварии в истории нефтегазовой добычи на месторождении «Тенгиз» (1985 г.) в Казахской СССР и Чернобыльской трагедии на атомной электростанции (1986 г.) в Украинской ССР (Гражданская защита, 2006).

Председатель Совета Министров СССР, член Политбюро ЦК КПСС Н.И. Ръжков, руководивший ходом работ по ликвидации последствий землетрясения в Армянской ССР, в интервъю в 2018 г. вспоминал, что первоначально не было ясно, «насколько все серъезно». Только когда он прибыл сам в Армению, то «понял, что на нашу страну упало тяжелейшее испытание. Это был второй удар. Первым был Чернобыль» (Трынова, 2018b).

В первые часы катастрофы на помощь пострадавшим были командированы части Вооруженных сил СССР. Из Москвы в Армению были отправлены 98 высококвалифицированных медицинских специалистов и военно-полевых хирургов во главе министром здравоохранения Е.И. Чазовым. В общей сложности 113 стран оказали гуманитарную помощь, включая Израиль, с которым у СССР отсутствовали дипломатические отношения. Спитакское землетрясение стало, с одной стороны, страшным испытанием, выпавшим на долю Армянской ССР - трагедией, сопоставимой по количеству жертв, покалеченных судеб, людей, потерявших кров, с крупномасштабными боевыми действиями, а с другой - пример консолидации и взаимопомощи советского общества перед лицом общей беды.

За прошедшие годы к Спитакской трагедии и ее последствиям обращались многие авторы. Среди них необходимо отметить В.И. Бондаренко, опубликовавшего в 2013 г. статью (Бондаренко, 2013), а через два года защитившего кандидатскую диссертацию (Бондаренко, 2015), в которых был подвергнут анализу вклад регионов России в ликвидацию последствий Спитакского землетрясения на примере Краснодарского края. В то же время нередко замещение научных знаний различными «теориями заговора», не имеющими под собой никакого не только теоретического, но и эмпирического основания. Например, О.О. Фейгином была озвучена версия о том, что СССР в 1988 г. «испытывал литосферное [вакуумное] оружие в отрогах Арарата», взрывная волна которого «рикошетом» «уничтожила Спитак» (Кашницкий, 2011).

За три с лишним десятилетия выросло целое поколение, которые уже не помнит ужасов Спитака и той помощи, которая была оказана пострадавшим районам. По словам Н.И. Рыжкова: «Сначала беда Армении перестала быть общей, а потом и вовсе забылась, как будто и не случилось никакого землетрясения» (Рыжков, 2011: 50). Поэтому для прояснения всех обстоятельств катастрофы важны публикации не только различных документов (Спитакское землетрясение, 2008 и др.), но и воспоминаний участников и очевидцев событий. В настоящее время они представлены в ряде периодических изданий, выходящих в разных регионах страны (Сердечная достаточность; Трынова, 2018а и др.), раскрывая участие их жителей в ликвидации последствий землетрясения.

Не оставались в стороне от общей беды и жители Донского края. Ростовская область в числе первых, наряду с соседними с Армянской ССР Азербайджанской ССР и Грузинской $\mathrm{CCP}$, не только оказывала гуманитарную помощь, но и направила кадры специалистов. Одной из организаций, выделивших сотрудников и безвозмездно предоставивших необходимую специальную технику, стало торгово-строительное объединение (ТСО) «Ростовстрой», а в числе ликвидаторов последствий оказался В.Д. Савенков.

Владимир Дмитриевич Савенков родился 15 апреля 1947 г. в г. Якутской АССР в семье политических ссыльных. В связи с бедственным положением семьи начал рано работать. С 16 лет - вздымщиком - сборщиком смолы хвойных пород деревьев, с 19 лет краснодеревщиком на лесозаготовительном предприятии. Получил производственную травму, частично лишился трех пальцев и был признан ограниченно годным к службе в военное время. В военном комиссариате Якутска по рекомендации отставных офицеров, которые не хотели полностью «списывать» в запас молодого человека, прошел курсы в 
1966 г., получил техническую специальность бульдозериста - машиниста бульдозера, гусеничного трактора с отвалом. В 1970 г. переехал в город Таганрог Ростовской области, работал на строительстве аграрных коммуникаций в Астрахани в период крупнейшей вспышки холеры. С 1977 по 1980 гг. участвовал в строительстве олимпийских объектов. В 1985-1986 гг. принимал участие в ликвидации последствий трагедии на нефтегазовом месторождении № 37 в городе Тенгизе Казахской ССР. В 1988 г. в связи с особым положением, был призван таганрогским военкоматом и принял участие в ликвидации последствий землетрясения в г. Спитак. В 1990-2000-х гг. работал в Казахстане и в России в Ростовской области, Ставропольском и Краснодарском краях. В настоящее время пенсионер с сорокалетним трудовым стажем.

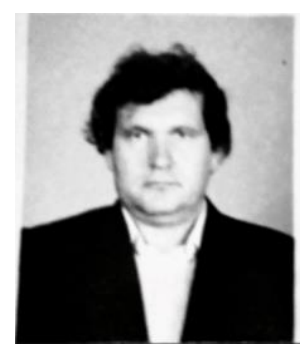

Рис. 1. Савенков Владимир Дмитриевич. Фото конца 1980-х гг. Семейный архив В.Д. Савенкова
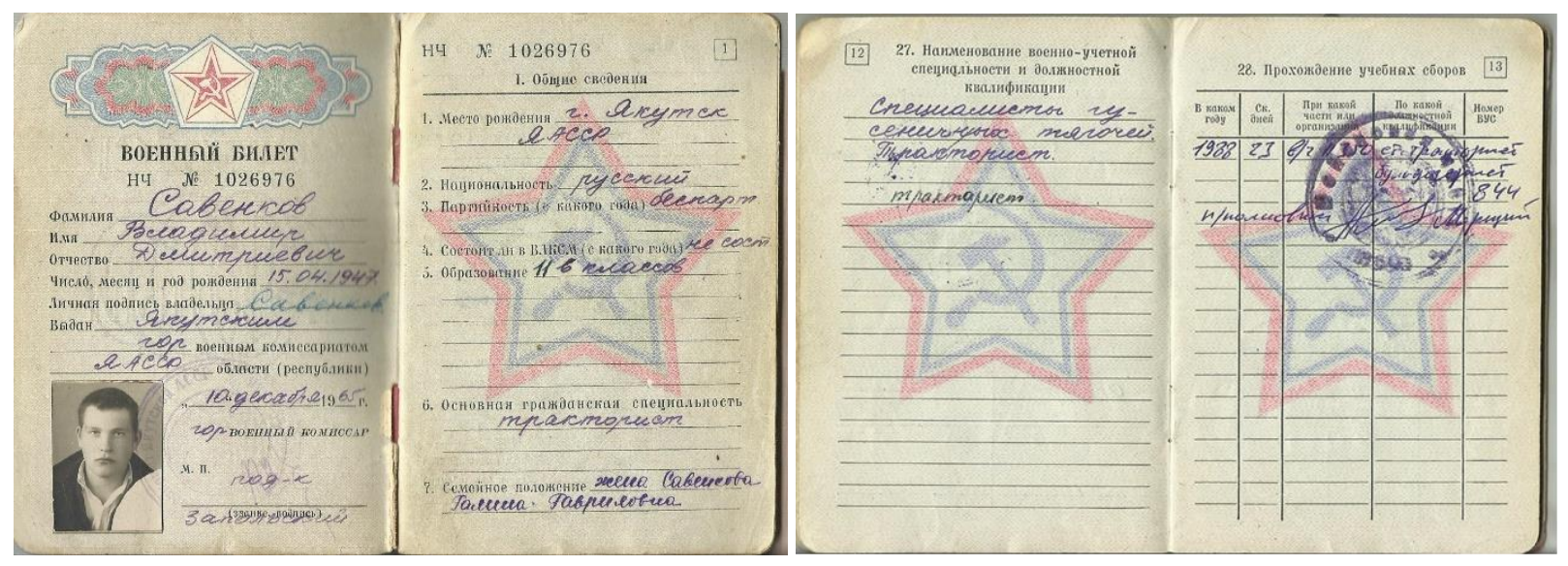

Рис. 2, 3. Военный билет В.Д. Савенкова, в котором в графе «Прохождение учебных сборов» указаны сведения об его участии в ликвидации последствий землетрясения в Спитаке с количеством дней, номером воинской части и ВУС

Семейный архив В.Д. Савенкова

Воспоминания В.Д. Савенкова были записаны в мае, августе и в сентябре 2021 г. Публикуются в соответствии с современными нормами орфографии и пунктуации. В квадратных скобках публикатором приведены недостающие слова. 


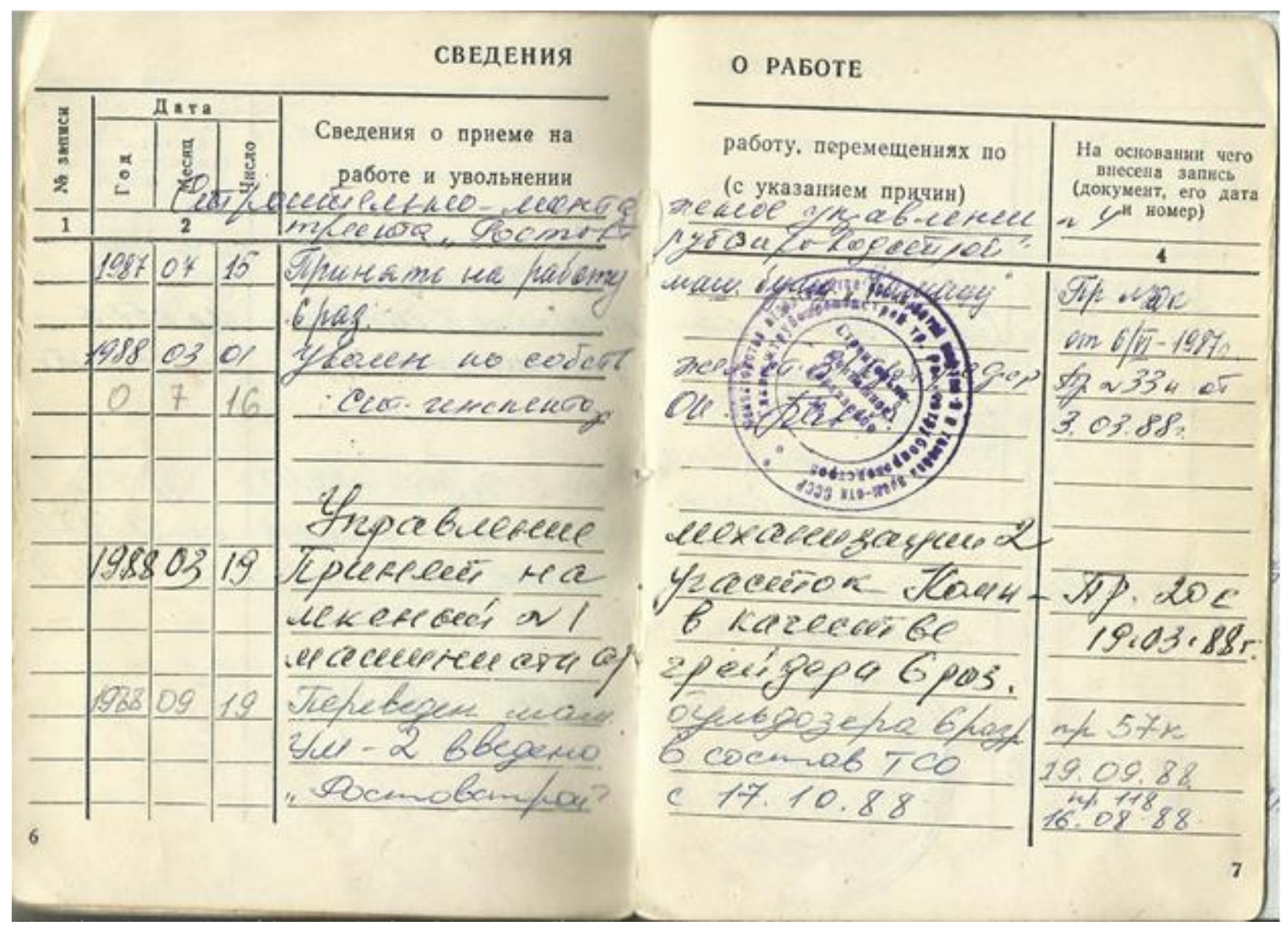

Рис. 4. Фрагмент трудовой книжки В.Д. Савенкова. Семейный архив В.Д. Савенкова

\section{Воспоминания Владимира Дмитриевича Савенкова}

\section{Владимир Дмитриевич, у Вас есть грамота участника ликвидации последствий трагедии в г. Спитак. Как Вы ее получили?}

Да, была такая, и долгое время хранил ее. Мне эту грамоту вручали в военкомате г. Таганрог, еще в далеком [19]88-м г., тогда мы с бригадой ребят участвовали в ликвидации землетрясения в Спитаке.

Армения находится в сейсмически опасной зоне и ее довольно часто «трясет». Можно ли считать данное событие уникальным?

Вовсе данное событие не было рядовым, после этой разрушительной катастрофы Армению так сильно давно не сотрясало. Это было ЧП ${ }^{1}$ всесоюзного масштаба, ни до, ни после столь мощных землетрясений на моей памяти не было ${ }^{2}$ СССР понес колоссальные денежные потери, а сколь огромное число людей было задействовано в восстановительных и спасательных работах...3 Люди буквально сгорали на работе, жертвуя здоровьем и пренебрегая правом на отдых! Работали вопреки всем физиологическим потребностям, а современные армяне уже и забыли, что Россия им помогала, кричат: «Россия бросила нас в Карабахе (2020 г.), никогда не помогала, а только выкачкой ресурсов и занималась!»

Вы помните имена и фамилии людей, с которыми работали в Спитаке?

Многих забыл, в связи с давностью, хотя в лицо помню некоторых ребят. Связано это с тем, что нас мобилизовали для нужд военных.

1 Чрезвычайное происшествие.

2 Трагедия 1988 г. в Армянской ССР являлось вторым по силе разрушительным землетрясением в СССР и уступала только Ашхабадскому землетрясению 6 октября 1948 г. в Туркменской СССР.

3 На ликвидацию последствий трагедии в Армянской ССР советским правительством была израсходовано около 10 млрд рублей (Трынова, 2018). 
Я правильно понимаю, что Вас призывал военкомат? Чем Вы занимались непосредственно в день трагедии?

В день трагедии, 7 декабря, я работал во второй смене в ПМК (УМ-2)ํㅜ на стройобъекте, однако меня попросили задержаться после работы для передачи важного сообщения. Поскольку по мою душу, со слов начальника, был звонок по телефонной линии. Многим позже я выяснил, что изначально предприятию была поставлена задача по предоставлению в первую очередь техники для строительно-дорожных работ. Сам же подбор персонала осуществлялся сотрудником военкомата уже с учетом рекомендаций начальства УМ-2. В УМ-2 я успел отработать месяц после перевода с другого филиала организации, это и сыграло решающую роль, поскольку позволяло сильно не нарушить текущие плановые работы.

После работы меня уже ждал трейлер² военкомата. А также вместе со мной, но уже на специальном транспорте, предназначенном для перевозки строительной техники, был отправлен и бульдозер.

Помните ли Вы марку бульдозера, который был направлен на работы? Техника была новой или с «пробегом»?

Я водил бульдозер марки Т-1303. Лично мой трактор был новый, в модификации Д3-110-М4, но техника была разной степени износа.

Я правильно понимаю, что Вас забирали во второй половине дня?

Нет, вторая смена заканчивалась вечером около 21-оо часа, забирали меня в ночь после работы.

Была ли предоставлена возможность собрать с собой какие-либо вещи первой необходимости или Вас сразу направили к месту трагедии?

Почему же, пару часов на сборы дали. А из одежды просили взять: две пары трусов, брюки гражданские и майку. Второй комплект, в виде брюк и майки, на себе вез, включая зимнюю одежду, поскольку было холодно. Высыпался я уже в трейлере, по пути к пункту распределения в Батайске. После быстрого оформления меня привезли и моего сменщика (на одном бульдозере полагается работать посменно) на большую стоянку тракторной техники к моему бульдозеру. Вся строительная техника впоследствии была размещена на специальных платформах, на которых обычно военную технику перевозили. Она так же была отправлена по железной дороге в Армению.

А почему Вас доставили к технике, а не сразу в вагоны поезда?

Мой бульдозер необходимо было перевести на платформу погрузки с импровизированной стихийной стоянки. Работы по грузопогрузке техники уже давно шли полным ходом без меня, видимо, с самой ночи. Тракторов и прочей техники стояло буквально машина на машине, видимо - не видимо. Погрузкой занимались водителиэксплуататоры и солдаты. Тракторную технику перегоняли на платформу для дальнейшей отправки. Моя задача заключалась в том, чтобы завести и перевезти бульдозер на платформу, а также лебедкой его зафиксировать, чтобы он не «сиганул» в сторону при движении поезда.

Технику вместе с Вами прицепом отправили или отдельно?

Нет, ее отправили отдельно, поскольку людей перевозили в иных условиях, на порядок хуже. Утром 8 декабря, после погрузки меня и других ребят посадили в набитые рабочими

\footnotetext{
1 ПМК - передвижная механизированная колонна - строительная организация в структуре Таганрогского металлургического завода, осуществляла деятельность с конца 1950-х гг. С 17 октября 1988 г. в качестве управления механизации (УМ-2) включена в состав ТСО «Ростовстрой».

${ }^{2}$ Фургончик для перевозки груза и военного состава.

3 T-130 - советский сельскохозяйственный и промышленный гусеничный трактор мощностью 160 л.с. Выпускался Челябинским тракторным заводом в различных модификациях с 1969 по 1988 г. (Бульдозер Т-170).

4 ДЗ-110 - бульдозер, выпускавшийся в различных модификациях Челябинским тракторным заводом на базе гусеничного трактора Т-130 с 1988 г. по 2002 г. (ЧТЗ, 2021).
} 
вагоны, раньше в которых перевозили коней, коров. Располагались эти вагоны на другой платформе ${ }^{1}$.

\section{Я правильно понимаю, Вас транспортировали до Армении в скотовозах?}

Да, в них наскоро, прямо перед нашим отъездом, были приделаны полки с настилами, в самих вагонах отсутствовали туалеты. В народе такие составы иронично называли «столыпинскими». Не скажу, чтобы нас везли, как скот, но как зэков - точно этапировали.

Вплоть до въезда в Республику Армению остановки не производились, но, если с малой нуждой мужчины как-то справлялись, посредством использования дверного проема вагона (двери не закрывались в целях циркуляции воздуха), намного сложнее обстояли дела с опорожнением кишечника. Прежде всего по двум причинам. Во-первых, в набитом людьми вагоне совершить данное действо было вовсе не гигиенично. А во-вторых, любая попытка высунуться тазом в дверь могла бы привести к серьезным травмам.

\section{Как долго ехали, как справлялись с тяготами?}

Ехали сутки. Большая часть пути пришлась на ночь, ближе к обеду было совершена первая остановка на 15 минут в населенном пункте близ Спитака, на вокзале. Помню, только поезд остановился, так сразу большая часть вагона, за исключением 3 человек, выбежала справлять большую нужду сразу под вагоны. Конечно, было стыдно, поскольку по вокзалу ходили женщины и дети бегали, однако физиологические процессы не отменишь, сразу у вагонов ребята «справлялись» под осуждающие взгляды прохожих. Не все побежали, но почти весь вагон опустел, кто-то конечно, как и я, воздухом вышел подышать, но таких были единицы. Примерно через 2-3 часа мы приехали, но не обошлось и здесь без происшествий.

\section{Происшествия какого плана произошли?}

Была дана команда, и мы завели наши трактора и вывели их с платформы. А далее мы двигались с железнодорожной станции своим ходом до места стоянки у элеватора, в котором в мирное время хранили зерно. Ты представляешь, что такое для спецтехники ехать 10-25 км² или более своим ходом? Сразу приходили в негодность катки на гусеницах. Этот рейд привел, в конечном счете, к простою большого числа строительно-дорожной техники. Несколько часов все работы не осуществлялись, пока нами не были проведены ремонтнопрофилактические мероприятия. Мой бульдозер тоже пострадал и не был исключением.

\section{работ?}

Иными словами, техника своим ходом не должна доставляться к месту

Да, кроме того, мы ехали по асфальту на большой скорости, поскольку всех маршброском гнали вперед, да еще на износ катков сказывался подъем в гору, а все это приводит порче и износу гусеничной техники.

\section{запомнился? \\ Вы упоминали элеватор для хранения зерна, он больше всего Вам}

В моей памяти навсегда запечатлелся этот перекошенный дом, который потом часто тиражировали в СМИ. Домом он был на первый взгляд, а на самом деле был элеватор. Даже несмотря, на то, что я проработал всего лишь месяц, разгребая завалы, данная картина стала для меня ассоциироваться с началом конца СССР, поскольку сохранялась атмосфера, что Советский Союз крепок и со всем справится, но на практике было видно, что руководство справляется из последних сил. Я навсегда запомнил перекошенный элеватор в затихшем Спитаке... Там находился наш полевой лагерь, а по правую сторону от элеватора работали французские поисковики с собаками․

\footnotetext{
19 декабря 1998 г. Председатель Совета Министров СССР Н.И. Рыжков призвал местные власти и гражданских служащих «не ждать команд сверху» и самостоятельно отправлять людей и машины в Спитак и Гюмри. Первоначально техника доставлялась в огромном количестве только из Азербайджана, Грузии и Северного Кавказа (Ростовской области), затем и из других регионов СССР. (Рыжков, 2009: 47-48).

2 Здесь, предположительно, идет речь об одноименной станции у г. Кировакан (с 1992 г. - Ванадзор), расстояние от Кировакана до Спитака 21 км (по прямой 18 км).

3 Н.И. Рыжков отмечал: «...собак, умеющих чуять людей под развалинами, у нас не дрессировали». Поэтому французские спасатели-поисковики прибыли первыми на место катастрофы (Рыжков, 2009: 48-49).
} 


\section{Перевалочный лагерь возник на пустыре.}

Да, практически так, как ты говоришь. По прибытию к нам сразу приехали военные транспортники и перебросили провиант и обмундирование, и ящики с дорогими по тем временам консервами и дефицитной минеральной водой. Мне запомнилась армянская минеральная вода, название которой запамятовал из-за труднопроизносимого названия, но помню, что ее не было в продаже на полках гастрономов.

\section{Название минеральной воды было не «Арзни»?}

Нет, как раз «Арзни» я хорошо помню. «Арзни» была дешевой и всегда в наличии, а та вода была редкой, ее на свадьбы доставали политработники и близкие к ним люди из номенклатуры.

Помимо минералки были сброшены тюки безразмерной военной формы, мы прямо там же, у ящиков примеряли на взгляд и брали с запасом, поскольку первоначально не были оговорены сроки нашего пребывания. Были и такие, кто намеривался набрать побольше, в надежде домой привезти для перепродаж, но ничего вывезти им не дали, равно, как и другие вещи с места трагедии, поскольку на кордонах при выезде всех обыскивала служба безопасности.

Исходя из Вашего рассказа, все события происходили стихийно. Лагерь так же был разбит второпях?

Да, все делалось наскоро. Помню, днем я ушел на объект, а в первые дни мы не особо работали на технике, а сооружали временное жилье для пострадавших, примитивное, по типу юрт у якутов или эскимосов - шалаши, обтянутые шкурами ${ }^{1}$. Вечером возвращаюсь со смены, темно, как у негра в лавке, и сразу мордой налетел на колючку и пробил кожу на бороде, и задел щеку. Что произошло? Пока мы работали, солдатики уже успели столбы врыть в землю и лагерь колючкой обтянуть, но я то этого не знал и пошел кратчайшем путем к палатке. Помимо упомянутого, уже были воздвигнуты полевые туалеты - колхозные уборные - дырки в полу и душ. манер?

Я правильно понимаю, что распорядок дня в лагере был на армейский

И да, и одновременно нет. Нас пытались приучить к армейской дисциплине. Например, очень смешной случай произошел утром, второго дня. Около 5-оо утра происходит попытка побудки, залетает дежурный, орет: «Япона-мама... такие-разэтакие, всем вставать!» Ребята не вставали сразу, поскольку, конечно же, устали, после поездки и рабочего ритма, но дежурный не умолкал. В этот момент происходят слабые сейсмические толчки, он падает, и чтобы удержаться на ногах, хватается за столб, который, к несчастью для него, оказался трубой раскочегаренной «буржуйки», печь хоть и слабо, но отапливала помещение ночью. Падение сопровождали крики, поскольку он при падении обхватил в объятия «буржуйку» и обжегся. Он орет, а в шалаше нашем дружный хохот. Кто-то даже сказал: «Ну что, будешь знать, как над работягами издеваться?» Обиженный дежурный стремительно вскочил на ноги, отплевался в нашу сторону и сказал: «Да ну вас!» Выскочил и побежал в санчасть, на этом все и кончилось.

\section{занимались? \\ Вы упомянули, что разгребали завалы, а чем конкретно Вы там}

Первостепенная работа бульдозера - это осуществление земельных работ по снятию первичного плодородного слоя почвы и демонтажные работы по ликвидации крупного строительного мусора. Я чистил дороги, для того чтобы гражданская техника и военные специалисты имели доступ непосредственно к завалам.

\section{Как осуществлялись поисковые работы, кто Вами руководил?}

Я на бульдозере был прикреплен с бригадой в помощь спасателям-медикам. Помимо меня, в расчистке территории участвовал рабочий на подъемном кране и ребята-поисковики под прямым руководством штатного начальника - младшего лейтенанта. Грубо говоря, на бульдозере я разгребал завалы на дорогах у бывших домов и то, что осталось от зданий.

\footnotetext{
1 Вопрос переселения пострадавших от последствий землетрясения жителей из временного жилья в более достойные условия так и не решен до конца, тогда как после Чернобыльской аварии (по данным ВОЗ/МАГАТЭ/ПРООН) в первые недели катастрофы были эвакуированы 116 тыс. из 350 тыс. пострадавших, а концу года были переселены и остальные пострадавшие (Винтон и др., 2005).
} 
Коллега на кране подымал плиты, которые некогда были домами, а моя роль заключалась в последующей зачистке объекта «под ноль».

\section{Были ли найдены под завалами Вами живые люди?}

К сожалению, живых людей не удалось найти, но под одной из плит был спасен выводок поросят. Произошло это следующим образом: на вторую неделю работ я расчищал объект, и как только были сняты обломки стен, под ними оказался погреб с деревянной дверью. Мне стало интересно, эту дверь мы с коллегой-крановщиком вдвоем дернули, а оттуда моментально выскочила свинья с целым выводком поросят. Как она бедная столько дней продержалась? Все дело в том, что животные более чувствительные к землетрясениям, многие повыбивались при первой тряске: ослики, овцы, собаки, коровы и другие, потом их туши находили на улицах, на их счет у меня были другие распоряжения, а люди при подземных толчках, наоборот, прятались по домам, где их обломками и подавило. Большей частью извлекались из-под завалов останки и фрагменты тел, чем живые люди. Хотя неоднократно обращались местные жители с просьбами помочь в поисках.

\section{С какой целью обращались гражданские лица?}

По личной инициативе. Например, к нам обратилась молодая женщина с просьбой очистить от завала дом, в котором до трагедии была люлька с дитем, в надежде его найти и по возможности спасти или на худой конец по-человечески похоронить. Ее дом представлял из себя до аварии небольшое двухэтажное здание. Все строение располагалось в одном квадрате. На первом этаже был гараж с машиной, а на втором жилой комплекс с детской комнатой. Во время землетрясения девушка успела выбежать, а машина загорелась и взорвалась. Выгорело буквально все дотла, естественно, мы ничего не обнаружили. Были и другие случаи - находили живых, однако наша бригада чаще всего доставала трупы, похороненные под шлаком, иногда конечности, а захоранивались они другими службами.

\section{Какие распоряжения существовали насчет трупов животных?}

Все трупы солдатами были снесены в отдельную кучу за городом, мне дали распоряжение на бульдозере вырыть ров, в который в последующем и были столкнуты туши. Затем их обильно засыпали хлоркой, и я же их захоранивал. Делалось это для предотвращения эпидемий, поскольку туши выделяют трупный яд.

\section{Какое настроение было у местных жителей?}

Сильно измученное. В основном, гражданские жители к нам во время работ не попадали, но у тех немногих, кто был, царило настроение глубокой подавленности. Никогда не забуду мужчину, который сидел возле своего разрушенного дома и не хотел уходить. Мы его спросили, почему не хочешь перейти хотя бы во временное жилье для пострадавших? На что он дал ответ: «Жена и дочка - все там лежат, для кого мне жить? Вот скажите мне?» ${ }^{1}$ Ответ, конечно, ему никто дать не мог.

Я правильно понимаю, что армию мобилизовали в помощь строительным бригадам?

Нет, были напрямую армейские части, с привлечением строительной техники. Наша бригада числилась за военно-санитарной частью, а солдаты были из стройбатов. Я отличался в бригаде трезвым образом жизни, из-за чего от медицинской бригады на меня была поручена особая миссия - первым заходить в полуразрушенные здания и разбивать все имеющиеся бутылки и скляночки с алкоголем до подхода военнослужащих.

\section{То есть, Вы препятствовали случаям массового пьянства?}

Нет, данная причина была не в пьянстве, а в связи с тем, что бывшие жители домов намерено оставляли бутылки с ядом. Яд, конечно же, подкидывали не из-за национализма армян к русским, а из-за желания хозяев домов данными действиями наказать потенциальных мародеров. Разбивая бутылки, я минимизировал риски отравления, как в бригаде, так и у мобилизованных солдат.

1 В 1914 г. российский психиатр Н.Н. Баженов опубликовал статью, посвященную жертвам Мессинского землетрясения 1908 г., где указывал, что пострадавшие получают схожую с военным временем душевную травму - посттравматическое стрессовое расстройство, которое проявляется в индифферентности и благодушии, безразличии к своей участи, потере концентрации, раздражимости и неспособности сосредоточиться. По мнению психиатра, это доказывало, что стрессовая ситуация способна привести к психическим заболеваниям (См.: Федунина, Бурмистрова, 2005). 


\section{Были реальные случаи отравления?}

Как мне сказали, были и достаточно много, из-за чего командование испугалось, и для предотвращения дальнейших ситуаций первым заходил я. А что мне? Зашел, банки бах-бах - побил, а далее влетали веселые солдатики, но затем выходили грустные, от того, что видели, что все спиртное ликвидировано.

\section{Вы заходили в брошенные дома?}

Да, в брошенные и полуразрушенные здания мы с бригадой часто заходили, поскольку перед сносом хоть сколько-нибудь уцелевшего объекта было необходимо его очистить от бытовой техники. Ее просто выносили и клали в сторону, чтобы она не мешала при демонтаже, а начальство само в дальнейшим ею распоряжалось.

\section{Было ли Вам страшно при работе в Спитаке?}

Страха не было, были моменты отвращения, когда просили вырыть яму, в которую потом были закинуты тела животных для погребения. А так в бульдозере не ощущаешь, разгребаешь, ли ты шлак с бытовым хламом или человеческими останками. Больше вызвало отвращение поведение людей. К нам обратился мужчина с просьбой поднять крышу дома, у которого разъехались стенки, ревел и просил помощи, уверял, что в доме дочь, которую придавило. Штатный начальник, который так же имел военное звание, дал добро. Была поднята крыша краном, в доме сохранилась кой-какая утварь и холодильник, но больше ничего. Пострадавший мужчина первым забежал, минут пятнадцать отсутствовал, а затем вышел с саквояжем, скорее всего, с деньгами, и был таков. А мы всей бригадой работали на разрыв - искренне хотели помочь, а тут такая меркантильность.

\section{Кому подчинялись военные формирования?}

Как мне показалось, при работе в первых днях действовало полное самоуправство и вседозволенность, вплоть до приезда на наш объект партийного министра Николая Рыжкова 1 .

\section{Председатель Совета Министров принял командование на себя?}

Нет, однако сразу после его визита весь офицерский состав был собран на совещание, на котором он долго и продолжительно всех ругал за разгильдяйство. В частности, был сделан выговор такого содержания: «Вы совсем дебилы - офицерам - всей обстановки не изучили? Как можно весь мусор и шлакоблоки свозить в поле, которое годами использовалось для посева? Армения - аграрная республика, годами производит для советской экономики сельскохозяйственную продукцию, а вы гектарами поля портите, чтобы немедленно все поле расчистили, и все до соринки вымели». После данного скандала уже стали останки городских строений свозить за 30 км, по асфальтной дороге и сбрасывать в Памбакское ущелье 2 .

Я правильно понимаю, что после отправки гусеничного транспорта по асфальту он приходит в негодность?

Правильно, весь асфальт остается межу стыков гусениц, однако дорога в данном отрезки была прочная и особо сильно не пострадала, после нас по ней ходил гражданский транспорт. Особая сложность заключалось в том, что не каждый оператор техники согласится на узкий аварийный участок свозить мусор, поскольку был высок риск сорваться. Но ничего, мы все справились, со мной вместе даже военный БТР с краном на борту был задействован, тоже свозил мусор. В целом, Рыжков молодец - навел «шороху», сразу начался порядок и гражданских лиц плавно стали демобилизовать.

\footnotetext{
${ }^{1}$ Н.И. Рыжков отмечал, что первым на месте трагедии оказался заместитель председателя Совета Министров СССР Б.Е. Щербина, находившийся по стечению обстоятельств с 1 декабря 1988 г. в командировке, а также первый секретарь ЦК Коммунистической партии Армении С.Г. Арутюнян. Прилет Н.И. Рыжкова состоялся утром 9 декабря и первоначально был запланирован завершиться 10 декабря (Рыжков, 2009: 46).

2 Памбакский горный хребет имеет протяженностью в 70 км, пролегает с северо-запада на юго-восток от города Спитак, в связи с вулканической природой возникновения, его отвесные скалы часто осыпаются и представляют наиболее аварийно-опасный участок дорожного движения в Армении (Рассел, Кохн, 2012).
} 


\section{Вас демобилизовали?}

Не всех гражданских специалистов демобилизовали, но меня отпустили домой к новогодним каникулам. Я поехал в первых рядах, поскольку был не пригоден к службе в мирное время, так как из-за производственной травмы не имел части пальцев на правой руке. Особое положение к этому моменту было снято, начались отправки домой. Ты представить себе не можешь, какое до явки Рыжкова творилось самоуправство. Кстати, со мной уехал мужчина - Коля, тракторист, вообще не имея ноги!

\section{Как такое возможно?}

Парень отслужил армию, по приезду уже дома получил травму, из-за чего впоследствии ему ампутировали ногу, однако в военкомате он не успел отметиться, вот его мобилизовали, как здорового! Куда они смотрели при отправке, чем руководствовались? Между прочим, наш земляк, с Ростовской области, инвалид, но от призыва не уклонялся!

\section{Владимир Дмитриевич, кратко опишите возвращение домой.}

Вывозить с территории Спитака ничего не полагалось, за этим следил КГБ. Однако мне все-таки в санитарной части подарили книгу по анатомии, которую выпросил. Я хотел по ней в последующем изучить болевые точки для массажа спины и поясничного отдела, поэтому попросил. Вагоны, в которых возвращался, в этот раз были гражданскими, но переполнены, уезжали с Колей на третьих полках плацкарта, по-солдатски.

\section{Бульдозер в этот раз на платформы не крепили?}

Нет, они уже навсегда остались в собственности Республики Армении, их конфисковали для нужд армии.

\section{Как же Вы работали без него?}

Первоначально я приехал в Батайск, отметился о прибытии, там у меня забрали грязный комплект военной формы, в котором я ехал, а мне вернули дорожную сумку со сменной одеждой, ту, что собирал перед поездкой. По возвращении домой, помылся, почистил зубы, и только на следующей день ушел на работу. На УМ-2 меня так рано, да еще без бульдозера, мягко говоря, никто не ждал. Поставили условие: «Либо восстанавливаешь старый и законсервированный, по причине поломки - бульдозер на базе трактора ТДТ-40², либо в отпуск за свой счет». За 1-2 дня я произвел диагностику бульдозера. По факту оказалось, что какие-то народные умельцы вместо поршня двигателя в цилиндре установили консервную банку, из-за чего бульдозер работал малое время и практически сразу «глох» после завода. В предприятии оперативно заказали необходимую деталь, а после ее установки, и я приступил к работе.

\section{Спитаке?}

Владимир Дмитриевич, была ли оплата за отработанный период с

Да, в размере MPOT³, но зарплату получал не на предприятии, а в таганрогском военкомате.

\section{Вы сохранили подаренную книгу по анатомии?}

Книга заключала в себе нюансы анатомического строения скелета человека и была особо мне безразлична. Сейчас так не принято, но в начале 1990-х г. еще сохранялась традиция, что если кто-то из жильцов многоквартирного дома отдавал учиться дочь или сына в университет, то помогали в сборах всем подъездом. У соседки по лестничной клети была девочка Лиза, а сейчас она уже женщина в возрасте. Она поступила в Ростовский

\footnotetext{
1 Комитет государственной безопасности в основном осуществлял контроль за детальностью иностранных спасательных миссий, поскольку со многим откликнувшимися на беду капиталистическими странами у руководства СССР были натянутые отношения. С первых часов катастрофы в Спитаке наблюдалась крупномасштабная деятельность мародеров, которые не гнушались снимать ценности с тел погибших. Для предотвращения противозаконных действий были мобилизованы военные части - около 20 тыс. человек (Минасян, 2008).

2 ТДТ-40 М - модифицированный советский дизельный трелевочный трактор Минского тракторного завода с мощностью двигателя в 40-45 л.с. Выпускался с 1956 по 1960 г. В 1969 г. оборудование и производственная документация были переданы в Китай в качестве технологической помощи (ТДТ-40). 3 МРОТ - минимальный размер оплаты труда с 1973 по 1991 г. составлял 70 рублей или около 17 тыс. рублей в пересчете на современный курс (Уразбахтина, Брагина, 2017).
} 
медицинский университет, моя покойная жена Галина передала книгу семье Лизы, данная книга помогла ей в учебе.

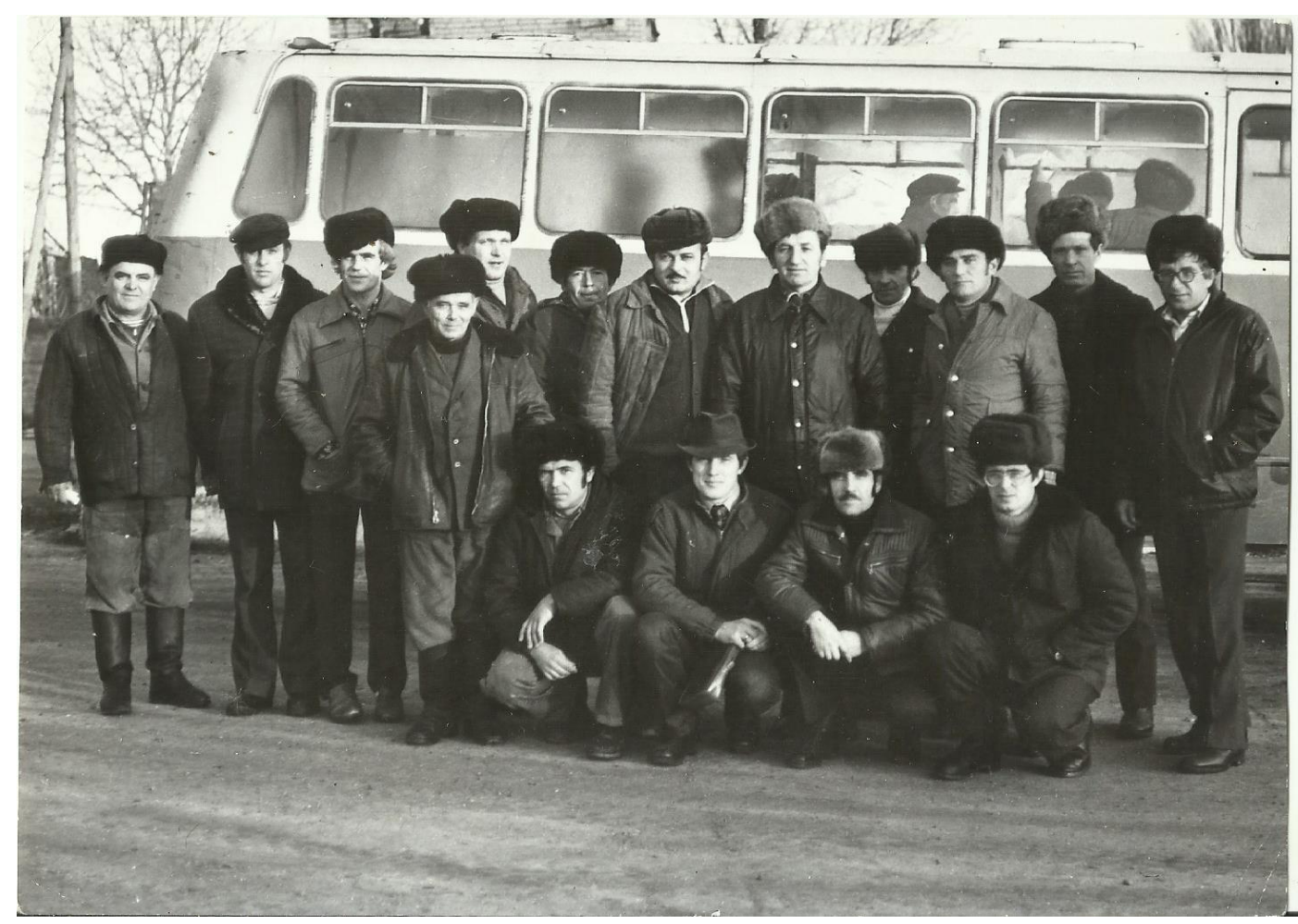

Рис. 5. Трудовой коллектив УМ-2. Четвертый слева - В.Д. Савенков. Четвертый справа - его сменщик Андрей Шкодич, вернувшийся после ликвидации последствий землетрясения с подорванным здоровьем, что привело к его скоропостижной смерти.

\section{Литература}

Бондаренко, 2013 - Бондаренко В.И. Помощь Краснодарского края в ликвидации последствий спитаксткого землетрясения 1988 г. // Теория и практика общественного развития. 2013. № 1. С. 232-235.

Бондаренко, 2015 - Бондаренко В.И. Вклад регионов России в ликвидацию последствий природных и техногенных катастроф в СССР во второй половине ХХ в. (на примере Краснодарского края): автореф. дисс... канд. ист. наук. Краснодар, 2015. 26 с.

Бульдозер Т-170 - Бульдозер Т-170 // Челябинский тракторный завод. [Электронный pecypc]. URL: http://chtz-uraltrac.ru/news/topics/532.php (дата обращения: 20.11.2021).

Винтон и др., 2005 - Винтон Л., Репачоли М., Балонов М. Чернобыль: истинные масштабы аварии. Совместный пресс-релиз ВОЗ/МАГАТЭ/ПРООН. Всемирная организация здравоохранения. Сентябрь 2005. [Электронный pecypc]. URL: https://www.who.int/ mediacentre/news/releases/2005/pr38/ru/ (дата обращения: 20.09.2021).

Гражданская защита, 2006 - Гражданская защита: Энциклопедия в 4 т. / Под. ред. С.К. Шойгу. Т. 1. М.: Московская типография № 2, 2006. 666 с.

Катастрофы конца XX века, 1998 - Катастрофы конца XX века / Под общ. ред. В.А. Владимирова. М.: УРСС, 1998. 400 с.

Кашницкий, 2011 - Кашницкий C. Оружие, которым пугал Хрущев, уничтожило Спитак // Аргументы и факты, 2011. №8. 23 февраля.

Минасян, 2008 - Минасян А. Спитакский разлом дышит. Двадцать лет спустя // Ноев ковчег. 2008, декабрь. № 12 (135). [Электронный ресурс]. URL: https://noev-kovcheg.ru/mag/ 2008-12/1448.htm l (дата обращения: 20.08.2021)

Рассел, Кохн, 2012 - Рассел Дж., Кохн Р. География Армении. М.: Bookvika publishing, 2012. 129 c.

Рыжков, 2009 - Рыжков Н.И. Главный свидетель М.: Алисторус, 2009. 480 с. 
Сердечная достаточность - Сердечная достаточность. К годовщине землетрясения в Спитаке: Воспоминания белгородцев, участвовавших в разборе завалов, и выдержки из газет 1988-1989 годов // БелПресса. [Электронный pecypc]. URL: https://www.belpressa.ru/ 25504.html (дата обращения: 12.09.2021).

Спитакское землетрясение, 2008 - Спитакское землетрясение. Зона бедствия вчера и сегодня. Взгляд через 20 лет: Сборник документов / Сост. А. Вирабян, А. Арутюнян, С. Мирзоян и др. Ереван: Национальный архив Армении, 2008. 640 с. (на армян. яз.).

ТДТ-40 - ТДТ-40 // МТ3-холдинг. [Электронный ресурc] URL: http://www.belarustractor.com/company/production-history/ (дата обращения: 20.11.2021).

Трынова, 2018а - Трынова A. «Город трясло ещё несколько дней»: воспоминания уральского врача о землетрясении в Спитаке. ОБЛГАЗЕTA.RU. 2018. 7 декабря [Электронный pecypc]. URL: https://www.oblgazeta.ru/society/incident/40802/ (дата обращения: 20.08.2021)

Трынова, 20186 - Трынова А. Спитак. Как спасали Армению // ОБЛГАЗЕТА.RU. 2018. 7 декабря. [Электронный ресурс]. URL: https://www.oblgazeta.ru/society/40807/ (дата обращения: 20.08.2021)

Уразбахтина, Брагина, 2017 - Уразбахтина E.P., Брагина T.E. Потребительская корзина от СССР до современной России // Россия: тенденции и перспективы развития. М.: ИНИОН, 2017. ВЫп. 12. Ч. 1. С. 584-585.

Федунина, Бурмистрова, 2005 - Федунина Н.Ю., Бурмистрова Е.В. Психическая травма. К истории вопроса // Московский психотерапевтический журнал. 2005. № 2. C. 164-190.

Яковлев, Балабан, 2018 - Яковлев А., Балабан E. Страшнее Чернобыля. 30 лет назад в Армении произошло одно из самых разрушительных землетрясений XX века. Пострадавшие до сих пор живут во временных домах // Mедуза. 2018. 7 декабря. [Электронный ресурс]. URL: https://meduza.io/feature/2018/12/o7/strashnee-chernobylya (дата обращения: 20.02.2021).

\section{References}

Bondarenko, 2013 - Bondarenko, V.I. (2013). Pomoshch' krasnodarskogo kraya v likvidatsii posledstviy spitakstkogo zemletryaseniya 1988 goda [Assistance to the Krasnodar Kray in eliminating the consequences of the 1988 Spitak earthquake]. Teoriya $i$ praktika obshchestvennogo razvitiya. 1: 232-235. [in Russian]

Bondarenko, 2015 - Bondarenko, V.I. (2015). Vklad regionov Rossii v likvidatsiyu posledstviy prirodnykh i tekhnogennykh katastrof $\mathrm{v}$ SSSR vo vtoroy polovine XX veka [Contribution of Russian regions to the elimination of the consequences of natural and man-made disasters in the USSR in the second half of the twentieth century (on the example of the Krasnodar Kray)]. PhD thesis (History). Krasnodar, 26 p. [in Russian]

Bul'dozer T-170 - Bul'dozer T-170 [Bulldozer T-170]. Chelyabinskiy traktornyy zavod [Chelyabinsk Tractor Plant]. [Electronic resource] URL: http://chtz-uraltrac.ru/news/topics/532. php (date of access: 18.05.2021).

Vinton i dr., 2005 - Vinton, L., Repacholi, M., Balonov, M. (2005). Chernobyl': istinnye masshtaby avarii. Sovmestnyy press-reliz VOZ/MAGATE/PROON. Vsemirnaya organizatsiya zdravookhraneniya. Sentyabr' 2005 [Chernobyl: the true scale of the accident. Joint WHO / IAEA / UNDP press release. World Health Organization. September, 2005]. [Electronic resource]. URL: https://www.who.int/mediacentre/news/releases/2005/pr38/ru/ (date of access: 20.09.2021).

Grazhdanskaya zashchita, 2006 - Grazhdanskaya zashchita: Entsiklopediya (2006) [Civil protection: Encyclopedia]. In 4 vol. / Ed. S.K. Shoigu. Vol 1. Moscow: Moskovskaya tipografiya No. 2, 666 p. [in Russian]

Katastrofy kontsa XX veka, 1998 - Katastrofy kontsa XX veka (1998) [Catastrophes of the end of the XX century]. Ed. V.A. Vladimirov. Moscow: URSS, 400 p. [in Russian]

Kashnitsky, 2011 - Kashnitsky, S. (2011). Oruzhiye, kotorym pugal Khrushchev, unichtozhilo Spitak [The weapon that Khrushchev used to frighten, destroyed Spitak]. Argumenty i fakty, February 23. [Electronic resource]. URL: https://aif.ru/society/science/23652 (date of access: 20.11.2021). [in Russian]

Minasyan, 2008 - Minasyan, A. (2008). Spitakskiy razlom dyshit. Dvadtsat' let spustya [Spitak fault breathing. Twenty years later]. Noev kovcheg. 12(135). December. [Electronic 
resource]. URL: https://noev-kovcheg.ru/mag/2008-12/1448.html (date of access: 20.08.2021). [in Russian]

Rassel, Kokhn, 2012 - Rassel, Dzh., Kokhn, R. (2012). Geografiya Armenii [Geography of Armenia]. Moscow: Bookvika publishing, 129 p. [in Russian]

Ryzhkov, 2009 - Ryzhkov, N.I. (2011). Glavnyy svidetel' [Chief witness]. Moscow: Alistorus, 480 p. [in Russian]

Serdechnaya dostatochnost' - Serdechnaya dostatochnost'. K godovshchine zemletryaseniya v Spitake: Vospominaniya belgorodtsev, uchastvovavshikh v razbore zavalov, i vyderzhki iz gazet 1988-1989 godov [Heart sufficiency. On the anniversary of the earthquake in Spitak: Memoirs of Belgorod residents who participated in the analysis of the rubble, and excerpts from newspapers of 1988-1989 yer's]. BelPressa [Electronic resource]. URL: https://www.belpressa.ru/25504.html (date of access: 12.09.2021). [in Russian]

Spitakskoe zemletryasenie, 2008 - Spitakskoe zemletryasenie. Zona bedstviya vchera i segodnya. Vzglyad cherez 20 let (2008) [Spitak earthquake. The disaster zone yesterday and today. A look in 20 years]. Collection of documents. Compl. A. Virabyan, A. Harutyunyan, S. Mirzoyan et al. Erevan: Natsional'nyy arkhiv Armenii, 640 p. [in Armenian]

TDT-40 - TDT-40 [TDT-40]. MTZ-kholding [[MTP-holding]. [Electronic resource]. URL: http://www.belarus-tractor.com/company/production-history/ (date of access: 20.11.2021). [in Russian]

Trynova, 2018a - Trynova, A. (2018). "Gorod tryaslo yeshcho neskol'ko dney": vospominaniya ural'skogo vracha o zemletryasenii v Spitake ["The city was shaking for a few more days": recollections of a Ural doctor about the earthquake in Spitak]. OBLGAZETA.RU. December 7. [Electronic resource]. URL: https://www.oblgazeta.ru/society/incident/40802/ (date of access: 20.08.2021). [in Russian]

Trynova, 2018b - Trynova, A. (2018). Spitak. Kak spasali Armeniyu [Spitak. How Armenia was saved]. OBLGAZETA.RU. December 7 [Electronic resource]. URL: https://www.oblgazeta.ru /society/40807/ (date of access: 20.08.2021). [in Russian]

Urazbakhtina, Bragina, 2017 - Urazbakhtina, E.R., Bragina, T.E. (2017). Potrebitel'skaya korzina ot SSSR do sovremennoy Rossii [Consumer basket from the USSR to modern Russia]. Rossiya: tendentsii i perspektivy razvitiya. Moscow: INION, Is. 12. Part 1, pp. 584-585. [in Russian]

Fedunina, Burmistrova, 2005 - Fedunina, N.Yu., Burmistrova, E.V. (2005). Psikhicheskaya travma. $\mathrm{K}$ istorii voprosa [Psychic trauma. On the history of the issue (Russian)]. Moskovskiy psikhoterapevticheskiy zhurnal. 2: 164-190. [in Russian]

Yakovlev, Balaban, 2018 - Yakovlev, A, Balaban, E. (2018). Strashneye Chernobylya. 30 let nazad v Armenii proizoshlo odno iz samykh razrushitel'nykh zemletryaseniy XX veka. Postradavshiye do sikh por zhivut vo vremennykh domakh [More terrible than Chernobyl, 30 years ago one of the most destructive earthquakes of the 20th century took place in Armenia. The victims still live in temporary houses]. Meduza, December 7. [Electronic resource]. URL: https://meduza.io/feature/2018/12/07/ strashnee-chernobylya (date of access: 20.11.2021). [in Russian]

\section{«Я помню перекошенный элеватор в затихшем г. Спитаке...»: Воспоминания ликвидатора спитакской трагедии 1988 г. машиниста бульдозера В.Д. Савенкова}

Подготовка к публикации, введение и комментарии

Владимир Дмитриевич Савенков ${ }^{\text {a , * }}$

а Таганрогский институт имени А.П. Чехова (филиал) Ростовского государственного экономического университета (РИНХ), Российская Федерация

Аннотация. В декабре 1988 г. руководство Ростовской области одним из первых, наряду с приграничными с Арменией союзными республиками оказало помощь

\footnotetext{
* Корреспондирующий автор

Адрес электронной почты: savenkov.stalker2010@yandex.ru (В.Д. Савенков)
} 
гуманитарного характера, предоставив квалифицированных специалистов организации «УМ-2» - ТСО «РОСТОВСТРОЙ» и необходимую для восстановительных работ специализированную технику.

Интервью Владимира Дмитриевича Савенкова посвящено его деятельности в качестве ликвидатора последствий катастрофического Спитакского землетрясения. Респондент подробно рассказывает о том, как осуществлялся его призыв и транспортировка техники, как ему приходилось приспосабливаться к специфике военно-спасательной операции и переносить все тяготы, связанные с особенностями экстренной дисклокации к месту ЧС. Воспоминания В.Д. Савенкова являются ценным свидетельством того, как ЧС в Армянской ССР выявила неподготовленность высшего партийного руководства, возглавляемого М.С. Горбачевым, по отношению к оперативной ликвидации и предупреждению крупных Чрезвычайных ситуаций городского типа.

Ключевые слова: В.Д. Савенков, Спитакское землетрясение 1988 г., «Ростовстрой», ликвидатор аварии, Армянская ССР, Ростовская область, воспоминания, устная история. 